\title{
Mod mytologisk realisme i Nikodemusevangeliet
}

\author{
Præsentation af Nikodemusevangeliet og dets \\ genskrivning af de kanoniske evangelier \\ Professor mso, ph.d. \\ Jesper Tang Nielsen, Københavns Universitet
}

\begin{abstract}
The Gospel of Nicodemus had its heyday in the Middle Ages. Today it attracts attention by only a few historians and practically no Biblical scholars. It is, however, a charming example of creative Biblical rewriting. The article provides an introduction to the text and its use of the New Testament gospels. It is possible to locate in it a number of typical narrative techniques and tendencies. This Gospel supplies the New Testament gospel narrative with new episodes and expands the known figures into new narratives. It aims to tell every detail from the New Testament in concrete narratives. In this way it moves in the direction of realism. At the same time it enhances the supernatural features of the narrative. In this way it moves in the direction of mythology. Thus, the Gospel of Nicodemus may tentatively be seen as a specimen of mythological realism.
\end{abstract}

Key words: Gospel of Nicodemus - Acts of Pilate - Rewritten Bible Narrative Techniques - Narrative Tendencies

Nikodemusevangeliet er ikke det mest udforskede af de såkaldt apokryfe nytestamentlige skrifter. I det hele taget er det tvivlsomt, om skriftet hører til blandt disse, for det er ikke med i alle udgaver. Og det er tvivlsomt, om man kan tale om ét skrift og i givet fald hvilket og af hvilket omfang. Ja, det er endda tvivlsomt, hvad det skal kaldes, for det går også under navnet 'Pilatusakterne' (Acta Pilati). Stort set alle forhold, der normalt hører under indledningsspørgsmål, kan for en gangs skyld ikke kaldes omdiskuterede, for de diskuteres ikke særligt meget. Til gengæld er de uafklarede. ${ }^{1}$

1. Se den begrænsede forskningshistorie i M. Schärtl, "Nicht das ganze Vol will, dass er sterbe." Die Pilatusakten als historische Quelle der Spätantike, Apeliotes. Studien zur Kulturgeschichte und Theologie 8 (Frankfurt a.M. etc.: Peter Lang 2010), 1214. Til denne skal tilføjes et dansksproget bidrag: Niels Willert, "Nikodemusevangeliet: Et kristent propagandaskrift midt i en brydningstid," Patristik 3 (2004), 1-32 (http://www.patristik.dk/Patristik3.pdf tilgået 19.11.2016); jf. N. Willert, Pilatusbilledet $i$ den antikke jødedom og kristendom, Bibel og historie 11 (Aarhus: Aarhus Universitetsforlag 1989), 331-334. 
Skriftet har haft sin storhedstid. Det findes i over 500 manuskripter, hvoraf nogle er på antikke sprog (græsk, latin, syrisk, koptisk, aramæisk, armensk, georgisk, oldslavonisk), andre på gamle europæiske (højtysk, lavtysk, hollandsk, oldfransk, italiensk, oldengelsk, middelengelsk, oldnorsk, walisisk, kornisk osv.). De mange versioner på stort set alle europæiske sprog fra middelalderen vidner om skriftets popularitet i denne periode. Mest populært var det i den latinske del af verden. 424 latinske manuskripter er bevaret. Oversættelserne til lokale sprog er foretaget fra den latinske tekst, skønt skriftet oprindeligt var på græsk. Som sagt, er interessen aftaget. Den eneste tekstkritiske udgave er C. von Tischendorfs Evangelia apocrypha fra 1853. ${ }^{2}$ Tischendorf rekonstruerer flere græske teksttraditioner til tekstens første del: Græsk A, Græsk B og de tilsvarende versioner på latin: Latin A og Latin B. Den formodentlig ældste tekst er Græsk A. Den dækker kap. 1-16, mens Græsk B dækker kap. 1-16 + kap. 17-27. ${ }^{3}$ Der findes kun én oversættelse af skriftet til dansk. ${ }^{4}$

Skriftet er et interessant udtryk for den type kreativ bibelfortolkning, som eventuelt kan kategoriseres under betegnelsen 'Rewritten Bible' eller 'Genskrevet Bibel'.5 Samtidig er det er et charmerende udtryk for, hvad der formentlig har været 'folkekristendom' eller 'populærteologi' i mange århundreder. ${ }^{6}$ Skriftet blev inddraget i gudstjenester og blev til tider ikke blot anvendt i prædikener, men også læst op sammen med de kanoniske tekster. Endvidere er dets indflydelse

2. Evangelia apocrypha (Leipzig: Avenarius et Mendelsohn 1853), 203-410. En ny udgave skulle være under udarbejdelse i serien AELAC.

3. Græsk A og uddrag af Græsk B (kap. 13-27) findes også med oversættelse til engelsk i B.D. Ehrman \& Z. Plese, The Apocryphal Gospels. Texts and Translation (Oxford: Oxford University Press 2011), 419-489. Denne udgave anvendes i det følgende. Til de tekstkritiske spørgsmål se nedenfor.

4. S. Giversen, Oldkristne tekster III. De apokryfe Evangelier (Herning: Poul Kristensens forlag 2002), 409-456. Jf. M. Müller, "Oversættelser af ikke-bibelske oldjødiske og oldkristne tekster”, DTT 66 (2003), 53-65.

5. Til diskussion af dette begreb se bidragene i J. Zsengellér (red.), Rewritten Bible after 50 Years: Texts, Terms, or Techniques. A Last Dialogue with Geza Vermez, JSJSup 166 (Leiden/ Boston: Brill 2014). Til begrebets historie se K. Dalgaard, „Rewritten Bible - Vermes' forbandelse“, Bibelske genskrivninger, red. M. Müller \& J. Høgenhaven, FBE 17 (København: Museum Tusculanum 2012), 19-49.

6. N. Willert mener, at skriftet er udtryk for en kalkedonensisk tonaturlære og således i overensstemmelse med den dominerende kirkelige teologi. Willert (2004), 31. Skriftets karakter og historie taget i betragtning kan man imidlertid let gøre det urette ved at kategorisere det i henhold til senantikkens kristologiske retninger. Det giver næppe udtryk for en veldefineret dogmatisk position. Angående Pilatusakterne (Græsk A) har R. Gounelle gjort sig til talsmand for, at de stammer fra et jødekristent miljø. R. Genoulle, "Un nouvel évangile judéo-chrétien? Les Actes de Pilate", The Apocryphal Gospels within the Context of Early Christian Theology, red. J. Schröter, BEThL 260 (Leuven: Peeters 2013), 357-401. 
i kunsten, litteraturen såvel som malerkunsten, vanskelig at overvurdere. Populariteten blev dog væsentligt mindre efter konciliet i Trient (1545-63). På grund af reformbevægelserne i den romerske katolske kirke optrådte blev det i 1564 sat på Index librorum prohibitorum. ${ }^{7}$

I det følgende skal Nikodemusevangeliet introduceres. Først med en gennemgang af dets indhold og dernæst en diskussion af traditionelle indledningsspørgsmål. Hovedinteressen samler sig imidlertid om skriftets narrative tilblivelse. Den behandles i den sidste del af artiklen. Det skal undersøges, hvordan Nikodemusevangeliets fortælling er opstået af de kanoniske evangelier, som det genskriver i den nye tekst. Af særlig interesse er de generelle narrative teknikker og tendenser, der findes i de innovative fortolkninger af de autoritative skrifter.

Det viser sig, at skriftet gennem episodiske udvidelser og figurative udfoldelser på den ene side fremhæver og udbygger de overnaturlige og fantastiske træk fra de nytestamentlige evangelier. Fremstillingen bliver således mere mytologisk. Samtidig udarbejder skriftet begivenheder og personer i konkrete detaljer. Dermed bliver det en mere realistisk fortælling. Genskrivningen af de kanoniske evangeliers passionshistorie bevæger sig derfor tendentielt i to modsatte retninger: mod det mytologiske og det realistiske. Det kan forsøgsvis samles i betegnelsen mytologisk realisme.

\section{Overblik over skriftets indhold: Pilatusakterne (Græsk A)}

Nikodemusevangeliet indledes i den form, som findes i Tischendorfs udgave, af en prolog. Selve skriftets fortælling indledes det sted i Jesu passionshistorie, der er kendt fra de nytestamentlige evangelier, nemlig da de jødiske lederes anklager Jesus for Pilatus for at fă ham dømt til døden (jf. Matt 27,1ff parr.). Det afsluttes imidlertid i en situation, der ikke findes i de kanoniske evangelier. Da har Jesus vist sig som opstanden for en række mennesker, som har aflagt vidnesbyrd for det jødiske råd. Undervejs udvides og udbygges den nytestamentlige fortælling stærkt.

Prologen er et klassisk eksempel på en forfatters fordobling. Forfatteren til skriftet identificerer sig ved navn Ananias. Han skriver i 17. år af kejser Flavius Theodosius II's regeringstid, hvor den kommende kejser Flavius Valentinianus II var seks år gammel, og det var i den

7. Z. Izydorczyk, "Latin Middle Ages", i samme, The Medieval Gospel of Nicodemus. Texts, Intertexts, and Contexts in Western Europe, Medieval \& Renaissance Texts \& Studies 158 (Tempe: Arizona State University 1997), 43-101 (101). 
niende indiktion, dvs. i året 424-25. Straks distancerer han sig imidlertid fra sit eget skrift ved at sige, at det er en oversættelse til græsk af officielle retsdokumenter, som han fandt på hebræisk. I indledningen angives det endvidere, at Nikodemus berettede alt, hvad der foregik i forbindelse efter Jesu lidelse og korsfæstelse og overgav det til ypperstepræsterne og de andre jøder. Samme Nikodemus samlede de hebræiske dokumenter. Oversættelsen består altså af de originale retsakter, som er skriftets første del (kap. 1-11). De kaldes nedenfor 'Pilatus-delen'. Hertil er koblet Nikodemus' øjenvidneberetning. Det er anden del (kap. 12-16). Nedenfor betegnes den 'Nikodemus-delen'. Indledningen indeholder desuden en overordentlig udførlig tidsangivelse: "det femtende år af romernes konge, kejser Tiberius' regeringstid og det nittende år af kongen over Galilæa, Herodes' regeringstid, otte dage før 1. april, dvs. d. 25. marts, i Rufus og Rubellios konsulat, i det fjerde år i den 202. Olympiade, mens Josef Kajfas var jødernes ypperstepræst."

Som sagt, indledes fortællingen, da ypperstepræsterne og de skriftkloge indkalder det jødiske råd til møde (jf. Matt 21,1 par.) og går til Pilatus for at anklage Jesus for mange ting. 10 af medlemmerne af rådet gives navne, nemlig Annas, Kajfas, Semes, Dathaes, Gamalial, Judas, Levi, Nefthalim, Alexander og Jairus. Hos Pilatus anklager de Jesus for at kalde sig selv Guds søn og konge, mens han samtidig bryder sabbatten, idet han helbreder lamme, krøblinge, visnede, blinde, stumme og djævlebesatte. På Pilatus' spørgsmål svarer de, at han gør det ved Beelzebul. Pilatus svarer, at man kun kan helbrede ved Asklepius $(1,1)$.

På jødernes opfordring vil Pilatus forhøre Jesus. Han sender sin kurer af sted for at hente ham. Da kureren skal bringe Jesus tilbage, lægger han sit tørklæde på jorden og beder ham gå på det. Jøderne beklager sig over den opførsel. Da Pilatus spørger, hvorfor han gør således, svarer han, at han har set hebræerne gøre sådan i Jerusalem, da Jesus kom ridende på et æsel, og de lovpriste ham med ordene fra Ps 118,26 (jf. Matt 21,1-9 parr.). En jøde oversatte det hebræiske tilråb for ham. Pilatus tillader, at han bringer Jesus ind på denne måde (1,2-4)

Jesus føres ind til Pilatus i en sal, hvor fanebærere står med faner. Da han kommer ind, bukker figurerne på fanerne for ham og tilbeder ham. Jøderne råber højt op imod fanebærerne, som de påstår, står bag fanernes tilbedelse af Jesus. Fanebærerne nægter, for de er grækere og slaver i templet. Pilatus beder jøderne udvælge tolv stærke mænd til at holde fanerne, men da Jesus atter går ind, bøjer fanerne sig igen (1,5-6).

8. Oversættelser fra Nikodemusevangeliet er mine. 
Det andet kapitel fører scenen videre. Pilatus bliver bange på grund af underet med fanerne og får samtidig besked fra sin kone, at han skal holde sig fra Jesus, for hun har lidt meget ondt på grund af ham (jf. Matt 27,19). Jøderne siger, at det bekræfter, at Jesus er en troldmand, for han har sendt onde drømme til Pilatus' kone $(2,1)$. Da forhøret begynder, svarer Jesus intet på jødernes anklager. Enhver har myndighed til at tale godt eller ondt. Det vil vise sig, hvad de taler, siger han $(2,2)$.

Jødernes ældste anklager ham for at være et uægte barn, avlet ved

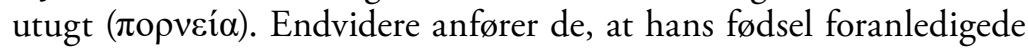
barnemordet i Bethlehem, og at hans forældre af den grund flygtede til Ægypten. Nogle af de fromme jøder siger dem imod. De ved, at Josef var forlovet med Jesu mor. Annas og Kajfas afviser dette udsagn. Det kommer fra proselytter og hans disciple, mener de. Der er tolv vidner for Jesus. De har navnene Lazarus, Asterius, Antonius, Jakob, Annas, Zeras, Samuel, Isak, Phineas, Crispus, Agrippus og Judas. De benægter at være proselytter og påstår, at de selv var til stede ved forlovelsesceremonien mellem Josef og Maria. Pilatus udspørger de tolv særskilt, og de overbeviser ham. Annas og Kajfas tager til genmæle og henviser til, at hele folkemængden mener, at han er et resultat af utugt, er en troldmand og kalder sig selv Guds søn og konge. Pilatus spørger de tolv, hvorfor folkemængden vil slå Jesus ihjel. Han får svaret, at de er forarget, fordi han har helbredt på sabbatten. De vil altså dræbe ham på grund af en god handling, spørger Pilatus. Ja, svarer de tolv (2,3-6).

Pilatus bliver vred og vil ikke dømme Jesus. Jøderne mener derimod, at de ikke kan dømme ham, for de må ikke henrette nogen (jf. Joh 18,30f). Pilatus forhører derefter atter Jesus på tomandshånd. Hans første spørgsmål er, om Jesus er jødernes konge. Forhøret omhandler samme temaer som forhøret i Johannesevangeliet (jf. Joh 18,28 - 19,16). Imidlertid er der flere forklarende tilføjelser. Når Pilatus afslutningsvis spørger "Hvad er sandhed?" Svarer Jesus "Sandhed er fra himlen." Pilatus spørger igen, om der ikke er sandhed på jorden, og Jesus svarer, at han selv kan se, hvordan det går dem, der taler sandheden. De dømmes af dem, der har magt på jorden (kap. 3).

Pilatus gør derefter endnu et forsøg på at frigive ham. Men jøderne opponerer og kræver, at Pilatus dømmer ham. Han er en blasfemiker, siger de, der sætter sig op mod kejseren (kap. 4). Herefter begynder en længere vidnerække for Jesus. Først Nikodemus, derefter en række af de mennesker, Jesus har helbredt, herunder kvinden med blødninger, der bærer navnet Bernike (i den latinske version: Veronika). Til sidst vinder flere fra skaren. Pilatus er i vildrede og siger igen, at han ikke forstår, hvorfor de vil spilde uskyldigt blod (kap. 5-8). 
Presset fra jøderne bliver dog for stort. Da de foretrækker Barnabas frem for Jesus (jf. Matt 27,15-23 parr.) og truer Pilatus med kejseren (jf. Joh 19,12), giver han efter. Han holder en tale om deres forhærdelse, men de erklærer, at deres konge er kejseren (jf. Joh 19,15). Flere gange siger de, at Jesu blod skal være deres ansvar. Pilatus dømmer ham til korsfæstelse sammen med to forbrydere ved navn Dysmas og Gestas (kap. 9). Korsfæstelsen finder sted, og Jesus lover den ene forbryder, Dysmas, at han skal være med ham i paradis endnu i dag (jf. Luke 23,39-43) (kap. 10). Da Jesus dør, siger han på hebræisk, “i dine hænder overgiver jeg min ånd”. Efter korsfæstelsen siger høvedmanden, at han var en retfærdig mand (jf. Luke 23,44-48). Han melder det til Pilatus. Både Pilatus og hans kone sørger dybt derover. Kvinderne fra Jesu omgangskreds står sammen med Josef af Arimathea og betragter det hele på afstand (kap. 11).

Her afsluttes Pilatus-delen. Fra dette sted forsvinder Pilatus ud af fortællingen, og Nikodemus overtager ifølge prologen ordet. Man kan i den forbindelse overveje, om det første udsagn i rækken af vidner (kap. 5) hører til samme redaktionelle lag som kap. 12-16. I så fald ville prologen, kap. 5 og kap. 12-16 være en senere udvidelse af de egentlige Pilatusakter.

Efter korsfæstelsen tager Josef af Arimathea sig af liget (jf. Matt 27,57-60 parr.). Det falder jøderne for brystet. De søger efter ham og dem, der vidnede for Jesus. Nikodemus og Josef står sammen mod jødernes trusler, men jøderne overmander Josef og spærrer ham inde. Da de den næste dag, på sabbatten, vil føre sag mod ham, er han forsvundet fra sit fængsel (kap. 12).

På det tidspunkt kommer gravvagterne til de jødiske ledere og fortæller om den tomme grav. De har oplevet, at en engel kom ned og væltede stenen fra indgangen. Selv om de blev som sten overværede de også englens samtale med kvinderne. De kan fortælle jøderne, at Jesus er opstanden og taget til Galilæa, for det hørte de englen sige. Jøderne bestikker vagterne til at sige, at Jesu disciple har stjålet liget (jf. Matt 28,2-14) (kap. 13).

Tre personer, en præst, en lærer og en levit, ved navn Phineas, Adas og Angaius, kommer fra Galilæa og beretter, at de har set den opstandne Jesus sammen med sine disciple på bjerget Mamilch. De overværede på afstand missionsbefalingen og himmelfarten, som den fremstilles i den sekundære Markus-slutning (Mk 16,15-18). Meddelelsen gør mange af de jødiske ledere meget bedrøvede, men Annas og Kajfas er snarrådige. De påstår, at Jesu disciple har bestukket gravvagterne til at fortælle om den tomme grav. De øvrige ledere mener dog ikke, at det forklarer, hvorledes Jesus nu ses i Galilæa. Annas og 
Kajfas kan ikke svare. De siger blot, at det ikke er tilladt at tro de uomskårne (kap. 14).

Nikodemus tager så ordet. Han foreslår, at de søger efter Jesus i Galilæa, for ligesom det var uklart, om Elias var blevet taget direkte op i himlen (jf. $2 \mathrm{Kg} 2,1-18$ ), således kan det være, at Jesus endnu befinder sig i Galilæa. De søger ham der, men finder kun Josef i Arimathea. Ham kalder de til Jerusalem, hvortil han kommer og bor hos Nikodemus. Hos Nikodemus vidner han for de jødiske ledere. Han fortæller udførligt om, hvordan Jesus befriede ham fra fængslet og bragte ham til Arimathea og bad ham blive hjemme i fyrre dage (Apg 1,3), mens han var sammen med sine disciple (kap. 15).

Lederne reagerer kraftigt på Josefs vidnesbyrd. De falder som døde til jorden. Kun på Nikodemus' opfordring står de op og begynder at tage føde til sig, fordi de skal være klar til sabbatten dagen efter. På den dag vidner Levi. Han fortæller, at han ved, at Jesu forældre var fromme mennesker, der gjorde, hvad de skulle efter Jesu fødsel (jf. Luk 2,25-35). Det har han nemlig fået at vide af Simeon, som tog imod barnet Jesus i templet. Levi var en af Simeons elever (16,13). Det bekræfter Levis far for jøderne. Herefter beslutter de atter at hidkalde de tre vidner fra Galilæa. De bekræfter deres vidnesbyrd, først sammen, derefter hver for sig (16,4-6). Til slut vidner de jødiske ledere selv. De fremfører argumenter fra de gammeltestamentlige skrifter for, at han kunne være blevet taget til himlen. De skete for Elias, Enok og Moses. Annas og Kajfas siger dem imod. Forskellen er, at Jesus gennemgik den ydmygende henrettelse og blev gennemboret af soldaten Longinus (jf. Joh 19,34). Alle ved, at han døde og blev begravet. Lederne enes om at se tiden an. Hvis han endnu er i erindring om et år, vil han skabe et nyt folk til sig selv $(16,7)$. Fortællingen slutter med, at de synger en hymne til Herrens pris. Skriftet afsluttes af en doxologi $(16,8)$.

\section{Overblik over skriftets indhold: 'Nedfarten til dødsriget' (Græsk B)}

Ovenstående referat dækker Græsk A, som har vidtgående overlap med første del af Græsk B. Forskellene mellem teksterne er dog så store, at de ikke uden videre kan kaldes tekstuelle variationer. Græsk $\mathrm{B}$ bestræber sig eksempelvis på at inkludere flere nytestamentlige detaljer, fx optræder Simon af Kyrene (Matt 27,32 parr.), og de tre galilæiske vidner siger, at de overværede missionsbefalingen på Oliebjerget sammen med femhundrede andre, hvilket bringer beretningen i 
overensstemmelse med 1 Kor 15,6. Afslutningen er naturligvis også anderledes, da der skal dannes overgang til nedfarten til dødsriget, som er indholdet af anden del af Græsk B. Efter en kortfattet udgave af forhøret af de tre galilæiske vidner, er der hverken Levis eller de jødiske lederes vidnesbyrd, men Josef af Arimathea tager ordet. Hans tale indleder den sidste del af teksten.

Josef siger, at det egentlig forunderlige ikke er Jesu egen opstandelse, men at han har opvakt flere, der har vist sig i Jerusalem. Bag dette udsagn ligger den mattheanske bemærkning "Og jorden skælvede, og klipperne revnede, og gravene sprang op, og mange af de hensovede helliges legemer stod op, og de gik ud af deres grave og kom efter hans opstandelse ind i den hellige by og viste sig for mange" (Matt 27,51b53). Josef fortæller, at to af de opstandne er kendte. Det er Simeons sønner, som nu er levende og bor i Arimathea. Jøderne beslutter at hente dem for at høre deres vidnesbyrd. De to brødre indvilger i at afgive beretning. De nedskriver deres oplevelser. Disse optegnelser er indholdet af sidste del af teksten (kap. 17).

De fortæller, at de var i Hades (dødsriget) sammen med alle de hensovede, da et stort lys brød frem. Ved dette vågnede de døde og profeter og patriarker blev samlet. Esajas siger selv, at det pågældende lys, var det, han havde profeteret om (Es 9,1-2). Til patriarker og profeter slutter sig Johannes Døber. Han præsenterer sig som den sidste profet, der har forberedt Herrens komme (Matt 3,3 parr.) og forkyndt om Guds lam, der bærer verdens synd (Joh 1,29), samt hørt røsten fra himlen ved hans dåb (Matt 3,16-17). Derfor er han nu sendt til dødsriget for at forkynde Guds søns komme (kap. 18).

Så kommer Adam og hans søn Seth. Adam opfordrer Seth til at fortælle om dengang, da Adam lå for døden, og Seth ville hente olie i paradis for at salve ham og helbrede ham. I paradis afviste en af Herrens engle ham. I stedet fik han at vide, at femtusinde femhundrede år efter skabelsen vil Guds egen søn komme til jorden som et menneske. Han vil salve med den livgivende olie og vaske ham i vand og Helligånd, både ham og alle hans efterkommere. De forsamlede patriarker og profeter glæder sig meget over dette (kap. 19).

På dette tidspunkt taler Satan og Hades sammen. Dødsriget er personificeret i figuren Hades, der bevarer de døde i sin mave. Satan vil forberede det på Jesu komme. Han har, siger han, haft succes med at få jøderne til at slå ham ihjel, om end Jesus gjorde meget mod Satans værk under sit jordeliv. Nu skal Hades være klar til at tage imod ham. Hades er bekymret. For kort tid siden blev en død mand ved navn Lazarus kaldt tilbage til livet ved et ord alene. Det tolker Hades som et tegn på, hvad der skal ske, og det beder Satan om ikke at bringe Jesus dertil, for så vil han sikkert oprejse alle de døde (kap. 20). 
Mens de taler sammen lyder der en stemme som torden: "Herskere, løft jeres porte, ældgamle porte, løft jer, og herlighedens konge vil drage ind" (jf. Ps 24,7). I resten af skriftet kaldes Kristus "herlighedens konge". Hades sender Satan ud for at kæmpe mod ham, og det får Hades’ dæmoner til at fæstne portene. Det er sikker på, at det vil føre til ødelæggelse, hvis herlighedens konge kommer ind. Mens dette sker, tiljubler profeterne og patriarkerne herlighedens konge, mens de nedgør Hades med ordene "Død, hvor er din brod? Dødsrige, hvor er din sejr?" (Es 25,8; Hos 13,14; 1 Kor 15,55). Så kommer stemmen atter, og herlighedens konges indtog formes som en dramatisering af Ps 24. Herlighedens konge slår dødsrigets porte ind og de fangne døde løslades (kap. 21).

Hades anerkender straks nederlaget til overmagten. Herlighedens konge griber Satan og overgiver ham til dødsriget, som skal holde ham fangen, indtil herlighedens konge kommer igen (jf. Apok 20,1-3). Hades tager Satan i sin varetægt og bebrejder ham, at han foranledigede, at herlighedens konge kom til dem. Alt, hvad Satan vandt ved visdommens træ, har han nu tabt ved korsets træ, siger han. Ved at ville slå herlighedens konge ihjel, har han slået sig selv ihjel (kap. 22-23).

Mens Hades irettesætter Satan strækker herlighedens konge hånden ud til Adam og rejser ham op. Også alle andre, der har lidt døden på grund af det træ, Adam rørte, bliver inviteret med. For herlighedens konge rejser nu alle op ved korsets træ. Alle sendes ud af dødsriget. Frelseren velsigner Adam og tegner korsets tegn på hans pande. Det samme gøre han ved alle andre. Under jubelsang begiver de sig til paradis (kap. 24).

Idet de kommer til paradis møder de Elias og Enok. Om begge fortælles det i Det Gamle Testamente, at de ikke døde, men blev taget direkte til himlen. De skal leve indtil endetiden, hvor de skal varetage de to vidners rolle i kampen mod Antikrist (jf. Apok 11,3-14). De skal kæmpe mod ham og blive dræbt, men derefter opstå og tages op i skyen til Herren (jf. 1 Thess 4,17) (kap. 25).

Efter at have mødt dem møder de en anden, ydmyg person. Det er den ene forbryder, der blev korsfæstet med Jesus. Han bærer sit kors på skuldrene. Han fortæller, hvorledes han efter korsfæstelsen kom til paradis og ærkeenglen åbnede for ham, da han så korset. Michael bad ham dog vente, for menneskehedens forfader, Adam, var på vej. Da alle de hellige hørte dette, hyldede de Herren for hans styrke (kap. 26).

Til slut fortæller de to brødre, at de blev sendt til Jordan, hvor de skulle døbes. Det blev de sammen med de andre, der var blevet oprejst fra de døde. Derefter kom de til Jerusalem for at fejre opstandelsens påske. Således omdefinerer Jesu opstandelse ifølge Nikodemusevangeliet påskens indhold fra første færd. Da brødrene har fortalt dette, 
forlader de med en fredshilsen jøderne. Bøgerne, som brødrene havde skrevet, fordelte de mellem sig. Ypperstepræsterne fik halvdelen, Josef og Nikodemus den anden halvdel. Efter dette forsvandt de. Skriftet slutter med en doxologi (kap. 27).

\section{Datering}

Som det er fremgik af indledningen, har Nikodemusevangeliet været kendt siden dets affattelse. Det er imidlertid ikke entydigt at sige, hvornår det var. Den nuværende version af teksten påstår at være skrevet i 424-25, men foregiver at være en oversættelse til græsk af en ældre hebraisk tekst, nemlig de officielle retsakter fra processen mod Jesus, samt Nikodemus optegnelser fra begivenhederne efter Jesu død. Endelig er "Nedfarten til dødsriget" også et selvstændigt afsnit, som angives som forfattet af Simeons sønner. Desuden viser den stærkt varierende manuskripttradition, at teksten er blevet bearbejdet mange gange i løbet af dens historie. Det forekommer derfor også sandsynligt, at de tre forskellige dele af teksten er skrevet på forskellige tidspunkter.

Manuskriptsituationen er på grund af skriftets popularitet på den ene side overvældende, på den anden side er manuskripterne relativt sene. Som sagt, er de allerfleste på latin. De er også de ældste, selv om der er enighed om, at skriftet er forfattet på græsk. De manuskripter, Tischendorf anvendte til rekonstruktionen af de græske tekster, er for Græsk A’s (kap. 1-16) vedkommende otte håndskrifter, der dateres fra det ellevte til det femtende århundrede. Til Græsk B (kap. 1-27) er det tre håndskrifter fra det syvende, fjortende og femtende århundrede og et håndskrift fra det femtende århundrede, der kun dækker kap. 13$16 .{ }^{9}$ Denne tekstsituation hjælper ikke dateringen meget, men der er grund til med S. Giversen at fremhæve to oversættelser, som indgår i Tischendorfs tekstgrundlag (jf. Giversen 2002, 417). Den ene er en latinsk palimpsest fra det femte århundrede, der i dag befinder sig $\mathrm{i}$ Wien og derfor kaldes Wiener-palimpsesten (Österreichische Nationalbibliothek MS. 563). Den bevidner store dele af Græsk A. Den anden er en oversættelse til koptisk (Papyrus no. 1, Museo Egizio di

9. Om manuskripterne se Ehrman/Plese, Apocryphal Gospels, 422.466; Schärtl, (2010), 17-19; samme, "Das Nikodemusevangelium, die Pilatusakten, und die Höllenfahrt Christi“", Antike christliche Apokryphen in deutscher Übersetzung. I. Band: Envangelien und Verwandtes. Teilband 1, red. C. Markschies \& J. Schröter (Tübingen: Mohr Siebeck 2012), 231-261 (236f) (= Schärtl 2012a). 
Torino) ligeledes fra det femte århundrede. Den indeholder en version af hele Græsk A. ${ }^{10}$ Teksten er altså ældre end disse oversættelser. En nøjagtigere dato må nås ved hjælp af den eksterne bevidnelse (jf. Izydorczyk \& Dubois, 1997, 22-27; Schärtl 2010, 20-28; 2012a, 233236; Willert 2004, 5-11.). Første henvisning til officielle retsakter fra processen mod Jesus findes hos Justin, der i sin Apologi (ca. 160) henviser læseren til sådanne akter for at forvisse om sandheden af hans historie om Jesus (Apol. 1.35.9). Han henviser tillige til, at disse procesakter skulle indeholde bevis for troværdigheden af Jesu undere (Apol. 1.48.3). Denne reference svarer til noget af indholdet i Pilatusakterne i Nikodemusevangeliet, men andre dele af Justins beskrivelse af korsfæstelsen er ikke i overensstemmelse med Nikodemusevangeliet. Endvidere henviser han også til optegnelser under statholderen Kvirinius, der skulle kunne bevise den folketælling, under hvilken Jesus blev født (Apol. 1.34.2). Hverken sådanne dokumenter eller den omtalte folketælling kendes andetstedsfra. Det kunne tyde på, at Justin blot forudsætter, at der har været sådanne akter, selv om han ikke selv har set dem. Eftersom intet andet hos Justin tyder på kendskab til Nikodemusevangeliet, er det ikke sandsynligt, at hans bemærkning omhandler dette skrift.

Omkring 197 nævner Tertullian i sin apologi et skrift fra Pilatus til kejser Tiberius (Apol. 5.2), og han betegner endog Pilatus som kristen ifølge hans indre overbevisning (Apol. 21.24). Selv om denne beskrivelse passer med fremstillingen af Pilatus i Nikodemusevangeliet, er det sikkert andre dele af den apokryfe Pilatus-litteratur, som Tertullian har haft adgang til, fx Pilatus' brevveksling. I hvert fald synes han ikke at kende retsakterne. ${ }^{11}$

Euseb refererer til Tertullians fremstilling af Pilatus' beretning til Tiberius i sin kirkehistorie (H.E. 2.2.1). Men heller ikke her findes en direkte reference til Pilatusakterne. Tværtimod nævnes anti-kristne Pilatusakter, der skulle have været i omløb under kejser Maximinus Daia (305/310-313) og være blevet brugt i skoleundervisningen (H.E. 2.1.9; 2.9.5-7). Havde Euseb kendt et kristent modskrift til de antikristne retsdokumenter, havde han sikkert nævnt det. Da hans kirkehistorie afsluttes omkring 325, må man antage, at Nikodemusevangeliet endnu ikke eksisterede.

10. Selve papyrussen er fra det tiende århundrede, men teksten kan af lingvistiske årsager sandsynligvis dateres til det femte århundrede. Z. Izydorczyk \& J.-D. Dubois, "Nicodemus's Gospel before and beyond the Medieval West", i Izydorczyk (red.) (1997), 21-41 (30). Tischendorf anvendte det i en latinsk oversættelse foretaget af A. Peyron til formålet. Tischendorf (1853), lxxii.

11. Til Pilatus-litteraturen se M. Schärtl, "Die sonstige Pilatusliteratur”, i Markschies \& Schröter (red.), (2012), 262-279 (= Schärtl (2012b)). 
Den første sikre reference til Pilatusakterne er i år 375 hos Epiphanius. I sin gendrivelse af alle kætterier diskuterer han påskens placering. Han nævner i den forbindelse quartodecimanerne, der vil fejre den kristne påske d. 14. Nisan, dvs. d. 25. marts. Denne datering skulle stamme fra Pilatusakterne (Pan. 50.1.5; 50.1.8). Samtidig påpeger han, at nogle versioner af akterne bevidner en anden dato.

En homilie af Pseudo-Chrysostomos fra 387 henviser også til dateringen af Jesu lidelse til 25. marts (otte dage før april) i Pilatusakterne. ${ }^{12}$ Denne gang med tilslutning. Forfatteren refererer til skriftet under det navn, som svarer til den overskrift Tischendorf sætter over Græsk A. Pesudo-Chrystostomos omtaler skriftet $\tau \grave{\alpha}$ vं $\pi$ o $\mu v \eta ́ \mu \alpha \tau \alpha \tau \grave{\alpha}$

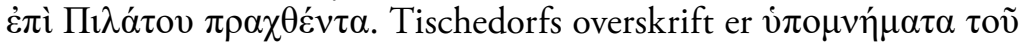

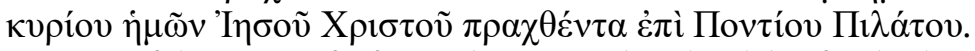

Ingen af de nævnte forfattere henviser til andre dele af Nikodemusevangeliet end de første elleve kapitler, som udgør Pilatusakterne.

I slutningen af det fjerde århundrede har Pilatusakterne altså været kendt i forskellige versioner i den østlige del af verden. ${ }^{13}$ I den vestlige del er den bevidnet fra det sjette århundrede. Gregor af Tours (ca. 539-594) skriver i sin Decem libri historiarum, at Josef blev fængslet og på mirakuløs vis befriet (1.21), og nævner, at Pilatus sendte en beretning om Kristus til Tiberius (1.24). Disse referencer er tydeligvis fra den del af Nikodemusevangeliet, som Nikodemus ifølge prologen er ophavsmand til.

På dette tidspunkt var Nikodemus' beretning kendt, men der nævnes intet om nedfarten til dødsriget. Den er først bevidnet på et manuskript fra det niende århundrede. Den del af teksten forekommer altså at være væsentligt yngre end de andre dele af Nikodemusevangeliet. Eventuelt går det tilbage til overleveringer fra det femte eller sjette århundrede (jf. Schärtl 2012a, 235f.). Det tyder en mulig henvisning til Nikodemusevangeliets version af nedfarten i påskehomilie af Pseudo-Chrysostomos fra det femte århundrede ${ }^{14}$ og $\mathrm{i}$ en påskesermon af Caesarius af Arles (ca. 468-542) fra første halvdel af det sjette århundrede på. ${ }^{15}$

12. F. Floëri \& P. Nautin (red.), Homélies pascales III. Une homélie anatolienne sur la date de paques en l'an 387, SC 48 (Paris: Editions du Cerf 1957), 126.

13. N. Willert mener ikke, at de omtalte Pilatusakter er identiske med første del af Nikodemusevangeliet. Han tager prologens datering for pålydende og mener, at Pilatusakterne er affattet omkring 425. Jf. Willert (2004), 26. Når man tænker på den foranderlige teksttradition, synes det dog ikke usandsynligt, at Pilatusakterne i Nikodemusevangeliet er en bearbejdelse af ældre tekster.

14. M. Aubineau (red.), Homélies pascales (SC 187; Paris: Éditions du cerf 1972), 305-337.

15. Sermo 160, PL 39, sp. 2059-2061; jf. A. Masser \& M. Schiller, Das Evangelium Nicodemi in spätmittelalterlicher deutscher Prosa. Texte (Heidelberg: Carl Winter 
Under alle omstændigheder bygger beretningen om nedfarten til dødsriget på ældre traditioner. Som bekendt er forestillingen om Kristi virke i dødsriget på dagen mellem gravlæggelsen og opstandelsen ikke bibelsk. Alligevel bliver forkyndelsen i dødsriget, frelsen af de døde retfærdige og overvindelsen af dødsmagterne en almindelig forestilling allerede i det andet århundrede. Forkyndelsen i dødsriget findes hos flere kristne forfattere fra det andet århundrede, fx Hermas (Sim. 9,16), Ignatius (Magn 9,2), Petersevangeliet (41f) og Justin (Dial. 72,4 (citat fra en Jeremias-apokryphon)), Ep.Apost. 27 (38). Den indgår som en fast bestanddel hos Irenæus (Haer. 1.27.3; 3.20.4; 4.22.1; 4.27.2; Epid. 78). I Hippolyts (ca. 170-235) kirkeordning fra begyndelsen af tredje århundrede indgår nedfarten til dødsriget i den bekendelseslignende beskrivelse af Kristus i nadverritualet $(4,8)$. Det lyder bl.a. "Han, som efter at være blevet forrådt til den frivillige lidelse for at gøre døden til intet, og bryde djævelens lænker, og trampe Hades under fode, og bringe lys til de retfærdige... tog et brød, takkede og sagde..." Når Kristi nedfart til dødsriget indgår i de officielle symboler fra synoderne i årene 359-360 (Sirmium, Nike og Konstantinopel) samt i den athanasianske og apostolske bekendelse, er det således en almindelig antaget forestilling, som dogmatiseres. ${ }^{16}$ Nikodemusevangeliets sidste tredje del er den fulde narrative fremstilling af trossætningen. Grundstammen i skriftet kan derfor meget vel være fra det fjerde eller femte århundrede, selv om dets endelige form er senere.

Man kan forsigtigt konkludere, at en tidlig form af selve Pilatusakterne (kap. 1-11) senest er opstået i tiden mellem Euseb og Epiphanius, dvs. midt i det fjerde århundrede. ${ }^{17}$ Muligvis som et modtræk til de anti-kristne Pilatusakter, som kom i omløb under Maximinus Daia og eventuelt som en bearbejdning af ældre argumenter fra jødiskkristne diskussioner om Jesu guddommelighed. ${ }^{18}$ Nikodemus-delen

Universitätsverlag 1987), 11.

16. Jf. R. Gounelle, La descente du Christ aux enfers. Institutionnalisation d'une croyance, (Collection des Études Augustiniennes Série Antiquité 162 (Paris: Brepols 2000). Til den religionshistoriske baggrund for motivet, J. Kroll, Gott und Hölle. Der Mythos vom Descensuskampfe (Leipzig/Berlin: B.G. Teubner 1932). N. Willert sondrer med rette mellem forkyndelsen i dødsriget og overvindelsen af dødsmagterne. Han finder, at Nikodemusevangeliet er udtryk for, at sidstnævnte fortolkning af Jesu nedfart til dødsriget vinder indpas i senantikken og til slut giver sig udtryk i tilføjelsen "nedfaret til dødsriget" i Apostolicum. Willert (2004), 32. Det kan dog præciseres, da udtrykket allerede er tilføjet i symbolerne fra Sirmium, Nike og Konstantinobel. Hippolyts kirkeordning viser, at motivet var kendt længe før.

17. R. Genoulle mener, at skriftet må skrevet samtidig eller kort efter Konstantins regeringstid og redigeret mellem 320-380. Genoulle, (2013), 371

18. Således Izydorczyk \& Dubois (1997), 40. M. Schärtl finder, at skriftets apologetiske karakter har sammenhæng med kejser Julian Apostatas restaurationspolitik i 360'erne. Schärtl (2012a), 238. Imidlertid må man med N. Willert påpege, at skriftet 
(kap. 12-16) er senest fra det tidlige femte århundrede, da prologen som nævnt angiver årstallet 425 . Opkomsten af et skrift fra Nikodemus' hånd i den periode ville passe med, at Nikodemus' grav og relikvier angiveligt blev fundet i 415 (jf. Schärtl 2010, 44f; 2012a, 238). 'Nedfarten til dødsriget' er formodentlig den yngste af de tre dele fra det femte eller sjette århundrede, men bygger på ældre traditioner.

Vanskelighederne ved dateringen svarer til problemerne ved overhovedet at bestemme en original tekstform. Teksttraditionen vidner om en flydende og smidig tekst. Manuskripterne afviger betragteligt fra hinanden og viser, at denne type litteratur er blevet fortalt og genfortalt, nedskrevet og genskrevet en lang række gange gennem århundrederne. Af samme grund kan man ikke operere med en enkelt forfatter til skriftet, der er blevet genskrevet og omskrevet mange gange. Som nævnt, mente Tischendorf at kunne rekonstruere to teksttraditioner med store variationer. Græsk B har en tendens til at inkludere flere nytestamentlige detaljer end Græsk A, herunder Simon af Kyrene og gennemboringen af Jesu side, hertil kommer en dødsklage, som Maria, Maria Magdalene og Josef af Arimathea holder, og andre mindre udvidelser (jf. Schärtl 2010, 159-165; 2012a, 236; Izydorczyk \& Dubois 1997, 29). Til gengæld er vidnesbyrdene i kap. 16 udeladt for at danne en lettere overgang til nedfarten til dødsriget. Endelig anvendes udtrykket $\theta \varepsilon$ cóóко $\varsigma$ om Jesu moder gentagne gange, hvilket synes at forudsætte konciliet i Efesos (431) (jf. Schärtl 2010, 164; 2012a, 236.). Disse forskelle viser, at Græsk A er ældst.

\section{Anledning og anliggende}

At Pilatusakterne er et modtræk til anti-kristen polemik og skrevet som et kristent alternativ til anti-kristne Pilatusakter, svarer udmærket til tekstens hovedmotiver. Det teologiske anliggende er ganske let at definere. Det handler om at bevise Jesu guddommelighed, hvortil et betydeligt argument er at modbevise rygterne om hans uægte herkomst. ${ }^{19}$ Derfor indgår dette motiv som en væsentlig del af anklagerne og de ti vidner for det modsatte indtager en fremtrædende position (2,3-6; 9,1). Hertil kommer, at Jesus fremstilles som mere utvetydig guddommelig og begivenhederne omkring ham er tydeligt overnaturlige. Særligt episoden med de hedenske symbolers

netop ikke viser tegn på modstand fra den hedenske omverden. Tværtimod synes det at afspejle en tid, hvor kristendommen ikke længere er forfulgt. Willert (2004), $28 f$.

19. Jf. Kelsos' anklage om, at Jesu mor skulle have begået ægteskabsbrud med en romersk soldat ved navn Panthera. Origenes, Cels. 1.32. 
tilbedelse af ham skal vise hans uimodståelige guddommelighed (1,56), ${ }^{20}$ men også listen af helbredte vidner om hans identitet (kap. 6-8). Derudover er det afgørende at friholde Pilatus for skylden for Jesu henrettelse. Selv om denne tendens også findes i alle de kanoniske evangelier, bliver den fremhævet og udbygget i Nikodemusevangeliet. ${ }^{21}$ Her erklærer han ikke blot Jesu uskyld flere gange og forsøger at løslade ham, men han tager selv til orde og taler mod jøderne om deres bestandige obsternasighed og stædighed mod deres velgørere og deres egen Gud, som det er kendt fra exodusberetningen $(9,2)$. Han vil endog forlade sin domstol. Kun fordi jøderne fortæller, at Herodes i forbindelse med barnemordet i Bethlehem har stræbt Jesus efter livet, fralægger Pilatus sig ansvaret og vasker sine hænder (9,34). Svarende til dette motiv pointeres jødernes eneskyld i Jesu død. Som i de kanoniske evangelier er det dem, der overtaler Pilatus. Men i Nikodemusevangeliet erklærer de selv, at de tager ansvaret. Hele tre gange gentages det skæbnesvangre udtryk fra Matthæusevangeliet 27,25: "Hans blod komme over os og vores børn" $(4,1 ; 9,4)$.

I Nikodemus-delen af skriftet er fokus ændret. Skylden for Jesu korsfæstelse er ikke i centrum, men derimod den fortsatte modvilje fra de jødiske lederes side. Det handler om at affeje alle mulige indvendinger mod Jesu opstandelse, så Annas og Kajfas til sidst står som prototyper på den jødiske forhærdelse (særligt kap. 16). Denne problematik synes at passe bedre i en situation, hvor der ikke er akut modstand fra officiel side, men snarere et behov for at befæste kristendommen internt ved at forvisse om, at afvisningen af Jesu opstandelse alene kan skyldes halsstarrighed.

Mens man således let kan forestille sig, at Pilatusakterne er et svar på udefrakommende anklager og påstande, som muligvis har været formuleret i anti-kristne skrifter, forekommer Nikodemus-delen at være et indre-kristent anliggende, hvor kristendommens forkyndelse

20. N. Willert påpeger en interessant sammenhæng med skildringen af Pilatus hos Josefus. Ifølge Josefus førte Pilatus på provokerende måde felttegn med kejserens billede ind i Jerusalem (Bell. 2,169-174; Ant. 18,55-59). Måske har sådanne traditioner givet anledning til en fortælling, der skal vise, at ikke kejseren, men Jesus er guddommelig. Willert, (2004), 22f; jf. Willert (1989), 68-74. Hvis det er tilfældet, taler det imod R. Genoulles udlægning, at Pilatusakterne i overensstemmelse med ebionismen fremstiller Jesus som almindeligt menneske. Genoulle (2013), 394-396. 21. Også denne tendens kan man se udvikle sig inden for de kanoniske evangelier. I Markusevangeliet overgiver Pilatus Jesus til korsfæstelse og frigiver Barabbas for at gøre jøderne tilpas (Mark 15,6-15). I Matthæusevangeliet erklærer han, at han ikke finder grundlag for at henrette Jesus og forsøger at frigive ham i stedet for Barabbas (Matt 27,15-23). Derefter vasker han symbolsk sine hænder for blodskylden (27,24-26). I Lukasevangeliet siger han tre gange, at Jesus er uskyldig (23,4.14.22). I Johannesevangeliet er det eksplicit, at Pilatus prøver at frigive ham (Joh 19,12). 
bekræftes ved at fremstille og afvise potentielle indvendinger gennem de stereotype jødiske modstandere. Pointen bliver, at alle ville være blevet overbevist om Jesu opstandelse og kristendommens sandhed, hvis det ikke havde været for de ufremkommelige jødiske ledere, der er personificeret i Annas og Kajfas (16,7). Samtidig bliver fremstillingen af de jødiske lederes vidnesbyrd en fordømmelse af den jødiske holdning i nutiden. De siger jo som Gamaliel (Acta 5,38-39), at tiden skal vise kvaliteten af troen på Kristus. Hvis den endnu findes et år efter, vil den vare evigt og et nyt folk vil opstå (16,7). I skriftets tid er det netop situationen, hvorved den jødiske modstand selv har afsløret sig som illegitim. Hertil svarer det forhold, at begrebet "Israel" i denne del af skriftet anvendes positivt om det folk, der skal komme til tro (16,7-8). I skriftet er der ikke plads til en jødedom ved siden af kristendommen. ${ }^{22}$ Således passer Pilatusakterne glimrende ind i en situation, hvor kristendommen etablerer sig som kejserrigets religion. Af den grund nedtones det fortidige konfliktfyldte forhold til romermagten, mens et konfliktuelt forhold til den aktuelle jødedom ligger under overfladen. Begge dele passer til situationen i det fjerde århundrede, hvor kristendommen fik officiel anerkendelse i Romerriget, og der foregik antijødiske kampagner fra både de romerske magthaveres og de kristnes side (se hertil Willert 2004, 27f.).

Spørgsmålet om anledningen til den tredje del af skriftet, "Nedfarten til dødsriget" er væsentligt vanskeligere at besvare. På sin vis synes teksten at være drevet af teologisk fortællelyst. Den er en narrativ udfoldelse af dagen mellem Jesu korsdød og hans opstandelse. Gennem fortællingen om den dag løses et teologisk problem, nemlig spørgsmålet om, hvad der sker med de generationer, der døde før Kristus. Trods den narrative form er svaret tydeligt teologisk. Grundlæggende gives der udtryk for en paulinsk Adam-Kristus-typologi (Rom 5). Hvad Adam satte over styr ved træet i Edens have, genvinder Kristus gennem korsets træ på Golgatha $(24,1)$. Således omvendes den skæbne, som Adam har påført menneskeheden. Ved korsets tegn velsignes Adam og alle patriarker, profeter, martyrer og stamfædre $(24,2)$, og de går alle sammen til paradis (kap. 25). Den teologiske pointe, at alle til alle tider frelses ved Kristus, er således præsenteret

22. Ph. Fackler mener, at Nikodemus-delen af Nikodemusevangeliet er et modtræk til anti-jødisk propaganda. I hans læsning ender skriftet med en fælles bøn for jøder og kristne, uden at kristendommen har fortrængt "jøderne" (det ord bruges slet ikke i Nikodemus-delen) som Guds udvalgte folk (Ph. Fackler, "Adversus Adversus Ioudaios? Countering Anti-Jewish Polemics in the Gospel of Nicodemus," Journal of Early Christian Studies 23 (2015), 413-444). Det er svært at følge Facklers pointe, for i Nikodemusevangeliet fremstilles de optrædende jøder kun positivt, fordi de fungerer som vidner for Jesus. 
narrativt. Det samme bliver den apokalyptiske forestilling om Satans overvindelse og fængsling i dødsriget (22,2; kap. 23), om end ideen om genkomsten og den endelige besejring af Satan ikke fortælles. Da Hades griber Satan udtrykkes endvidere en særlig forståelse af Jesu død. Hades siger til Satan, at det netop er i kraft af korsdøden, at han var i stand til at tage magten fra dem (kap. 23). Det er faktisk den eneste teologiske forståelse af korsdøden, som hele skriftet giver udtryk: Korsdøden er anledningen til overvindelsen af dødsriget og frelse af de døde hellige. Denne opfattelse kan man finde andre eksempler på $\left(\mathrm{fx}_{\mathrm{x}} \mathrm{ApoBA} \mathrm{A}^{23}\right)$, men den giver ikke grundlag for at placere skriftet i nogen specifik kontekst. Teologisk passer tekstens indhold tillige til snart sagt et hvilken som helst tidspunkt i antikken.

\section{Narrative teknikker og tendenser}

Det er hævet over enhver tvivl, at forfatterne til Nikodemusevangeliet har haft alle fire kanoniske evangelier til rådighed. ${ }^{24}$ Spørgsmålet er imidlertid, om man kan sige noget om, hvordan forfatterne har brugt og bearbejdet de evangelier, som ligger til grund for skriftet. På en måde er det naturligvis et umuligt spørgsmål at besvare. Forfatterne til apokryfe skrifter er som alle andre forfattere ikke bundet af regler og love, men skaber deres værker ved fantasi og kreativitet. Ikke desto mindre kan man uddrage nogle teknikker og tendenser, som viser, hvorledes fortællinger typisk udvikler sig, når de genfortælles og genskrives. ${ }^{25}$ Man kan definere tre niveauer, hvorpå udviklingen finder sted.

23. På side 97 på håndskriftet P. Berol. 22220, der var kendt under navnet Frelserens Evangelium, står der: "Hvis jeg har helbredt dem, der hører verden til, er det også passende for mig at gå ned til dødsriget for de andres skyld, som er bundet på det sted." Jf. J.T. Nielsen, "Berlinerapokryfen eller Apocryphon Berolinense/Argentoratense (ApoBA) - tidligere kendt som Frelserens Evangelium (Gospel of the Savior). Indledning og oversættelse af tre håndskrifter (P. Berol. 22220, Strasbourg Copte 5-7, Kasr el-Wizz Kodeks)," DTT 78 (2015), 82-112.

24. Jf. Willert (2004), 15-19 for en gennemgang af relationer til Matthæus-, Lukas- og Johannesevangeliet. Der er ingen grund til, at forfatterne ikke også skulle have kendt Markusevangeliet. Skriftet har en forkærlighed for Lukas- og Johannesevangeliet. Det synes ikke et oplagt valg, hvis baggrunden er jødekristen, som R. Gounelle mener. Genoulle (2013)

25. I sagens natur kan man finde lignende teknikker i andre former for genskrivninger fra andre tider, således har Anders Klostergaard Petersen og jeg - uafhængigt af hinanden - draget paralleller til Disney-tegneren Don Rosas bearbejdning af Carl Barks' historier om Onkel Joakim. A.K. Petersen, "The Riverrun of Rewriting Scripture: From Textual Cannibalism to Scriptural Completion,” JSJ 43 (2012), 475-496; J.T. Nielsen, „Fødselshistoriernes narrative konstruktion,“ Historie og kon- 
Strukturelt er der ingen tvivl om, at de kanoniske evangeliers grundforløb danner grundlaget for Nikodemusevangeliets fortælling. Det er forløbet fra de jødiske lederes rådssamling og overgivelse af Jesus til Pilatus og frem til opstandelse og himmelfart, som udgør det grundlæggende ramme for skriftets forløb. I Nikodemusevangeliets version af det forløb findes stort set samtlige episoder fra de kanoniske evangelier, selv om de for nogles vedkommende gengives fra et andet perspektiv eller i en ny fortolkning. Men udover de kendte episoder indføjer forfatterne også nye ellers ukendte episoder. Man kan kalde det en episodisk udvidelse af den forudgivne kanoniske struktur. I skriftets første del sker det i forbindelse med Jesu indkaldelse til forhør. Kurerens måde at føre Jesus til Pilatus på, hvori der er indflettet en gengivelse af indtoget i Jerusalem set fra kurerens synspunkt (1,24 ), er en sådan episodisk udvidelse. Det er også episoden med de hedenske faner og symboler, som tilbeder Jesus (1,5-6). Episoderne indføjes i strukturen, men bidrager ikke til fortællingens udvikling. De skal understrege nogle af fortællingens pointer, in casu den romerske velvilje og Jesu overlegne guddommelighed, men fortællingens forløb er uberørt af udvidelsen. Som Aristoteles påpeger i sin Poetik, kan der $i$ en hel fortælling indføjes episoder ad libitum. Det ændrer kun på fortællingens længde (ArPoet 1455a15-23). Hele Nikodemus-delen er ligeledes en episodisk udvidelse. Trods den meget anderledes fremstilling i denne del af Nikodemusevangeliet ligger grundskemaet fra den kanoniske fortælling til grund for beretningen om jødernes reaktion på Jesu opstandelse. Man kan konstatere det kanoniske skema i de begivenheder, som gengives i referat fra personer, der har oplevet dem. Det gælder beretningen om den tomme grav (kap. 13), missionsbefaling og himmelfart (kap. 14). Mens dette skema så at sige ligger under Nikodemusevangeliets fortælling, består den af episodiske udvidelser, fx Josefs fængsling og mirakuløse befrielse (kap. 12), eftersøgningen efter Jesus $(15,1)$ samt diverse vidnesbyrd $(15,5-6$; kap. 16). Med G. Genettes termer kan man sige, at den kanoniske fortælling er hypotext, som hypertexten forholder sig til, når den ændrer perspektivet for begivenhederne og tilføjer episoder. ${ }^{26}$ Nedfarten til dødsriget er for så vidt én stor episodisk udvidelse. Dens forhold til den kanoniske grundtekst er imidlertid lidt anderledes, da den har sit udspring i en bestemt detalje. Det er bemærkningen om de åbne grave og de dødes opstandelse (Matt 27,51b-53), der er anledningen til udvidelsen. Man kan sige, at nedfarten til dødsriget konstrueres som en episode ved en narrativ udfoldelse af den mattheanske detalje.

struktion, red. M. Müller og T. Thompson, FBE 14 (København: Museum Tusculanum 2005), 319-335.

26. G. Genette, Palimpsestes. La littératur au second degrè (Paris: Seuil 1982). 
Ved at kreere en fortælling om de åbne grave og de dødes opstandelse med specifikke personer bliver der plads for en førstehåndsberetning om nedfart til dødsriget, der udgør en episode i fortællingen.

Der er direkte sammenhæng mellem den narrative udfoldelse af detaljer fra hypotexten til det næste niveau. Man kan kalde niveauet figurativt og den narrative teknik figurativ udfoldelse. Den finder sted, når hypertexten udvikler figurative, spatiale eller temporale elementer fra hypotexten, dvs. en kreativ videreudvikling af fx personer og ting, omstændigheder og forhold. En måde at udvikle de optrædende figurer på er at forlene dem med navn. Det er karakteristisk, at mange personer, fx medlemmerne af det jødiske råd $(1,1)$, de tolv vidner $(2,4)$, kvinden med blødninger (kap. 7), røverne, der kostfæstes med Jesus $(9,5)$ soldaten, der gennemborer Jesus med et spyd $(16,7),{ }^{27}$ der i Det Nye Testamente er anonyme, i Nikodemusevangeliet navngives. En anden slags figurativ udfoldelse findes, når figurernes for- eller efterhistorie fortælles. Således er det karakteristisk, at bipersoner fra Det Nye Testamente udfoldes og får en selvstændig historie i Nikodemusevangeliet. Det er tilfældet for Nikodemus i Pilatusakterne, for Josef i Nikodemus-delen og for Simeons sønner i nedfarten til dødsriget. Ligeledes bliver Annas og Kajfas overalt udfoldet som stereotype jødiske modstandere. Samtidig etableres gennem den figurative udfoldelse nye relationer. Simeon får Levi som discipel, Josef og Nikodemus bliver venner. Ved at udfolde de kendte figurer og introducere nye, $\mathrm{fx}$ de galilæiske vidner og Simeons sønner, skabes der mulighed for nye perspektiver og nye episoder i fortællingen. De galilæiske vidner beretter om missionsbefalingen og himmelfarten fra et andet perspektiv og lader således også denne del af den kanoniske historie komme jøderne for øre. Simeons sønner fortæller om nedfarten til dødsriget. ${ }^{28}$ Samtidig med at nogle figurer udfoldes og udvides, bliver andre integreret og kombineret. Det er tydeligt i vidnerækken, hvor de helbredte vidner for Jesus. I disse kombineres detaljer fra forskellige helbredelsesberetninger i en person. Således er den lamme, der er blevet helbredt, både den synoptiske figur, der blev båret til Jesus på en båre (Matt 9,2 parr.), og den johannæiske person, der havde været syg i 38 år (Joh 5,5).

27. Som regel er det ikke muligt at se en logik i, hvilke navne anonyme personer tildeles. Men i dette tilfælde synes det klart, at navnet Longinus stammer fra det græske ord for spyd $\lambda$ ó $\gamma \chi \eta$.

28. At det netop er Simeons sønner, der udfoldes figurativt til denne opgave, er sikkert begrundet i Simeons udsagn: "Se, dette barn er bestemt til fald og oprejsning for mange i Israel og til at være et tegn, der modsiges" (Luk 2,34). Det citeres flere gange i Nikodemusevangeliet $(16,2.6 .7)$. Ved at Simeons sønner varetager vidnefunktionen for nedfarten til dødsriget bringes dette citat i erindring kombineres med Matt 27,52f., så den omtalte "oprejsning" bliver opstandelsen fra de døde. Jf. Fackler (2015), 438. 
Endelig er der niveauet med figurernes tale. På dette retoriske niveau er der naturligvis uendelige muligheder for variation. Personerne i bypertexten kan tillægges allehånde udsagn og udtalelser. På grundlag af hypotexten kan der konstrueres nye taler og konversationer ad libitum. Det interessante er, hvad der sker, når der er en konkret nytestamentlig baggrund for en tale eller samtale. Hvordan konstrueres nye replikker på baggrund af de kanoniske? Forhøret for Pilatus (kap. 3) er et eksempel på et replikskifte med klar johannæisk baggrund. Store dele af samtalen er gengivet direkte efter Johannesevangeliet, således også Pilatus' afsluttende bemærkning "Hvad er sandhed?" (3,2; jf. Joh 18,38). I Nikodemusevangeliet svarer Jesus på spørgsmålet. Han siger: "Sandhed er fra himlen." Pilatus spørger igen: "Er der ikke sandhed på jorden?” Hertil svarer Jesus: "Du kan se, hvordan de, der taler sandheden, dømmes af dem, der har magten på jorden." Pilatus' spørgsmål, som i Johannesevangeliet er bevidst enigmatisk, bliver tydeliggjort i Nikodemusevangeliet. På samme måde udspecificeres Jesu udsagn i Johannesevangeliet "Du havde ingen som helst magt over mig, hvis ikke det var givet dig ovenfra" $(19,11)$ til et konkret udsagn om Pilatus' begrænsede handlemuligheder. Pilatus spørger Jesus: "Hvad skal jeg gøre med dig?" Jesus svarer: "Som det er blevet givet dig." Pilatus: "Hvorledes er det blevet givet?" Jesus forklarer derefter, at Moses og profeterne har forkyndt om hans død og opstandelse $(4,3)$. Hvad der i Johannesevangeliet står ubestemt og tvetydigt, bliver i Nikodemusevangeliet bestemt og entydigt. Det samme sker i kraft af gentagelser af udsagn, der i de kanoniske evangelier kun optræder én gang. Sætningen "hans blod komme over os og vores børn" (jf. Matt 27,24-25) findes hele tre gange i Nikodemusevangeliet (4,1; $9,4 ; 12,1)$. Gentagelsen skal tydeliggøre jødernes bevidste overtagelse af ansvaret for Jesu død. Ligeledes er de nye konstruktioner, fx Pilatus' tale til jøderne $(9,2)$, blevet til for at entydiggøre Pilatus' figur. Han tager utvetydigt til genmæle mod jøderne og bekræfter deres skyld og sin egen uskyld. Det er således en teknik på dette niveau at konstruere nye udsagn og taler, som udfolder og tydeliggør meningen med de kanoniske replikker, som ligger til grund i hypotexten. På samme måde kan man konstatere, at personer, der i de kanoniske forlæg stod for en tvetydig holdning, fx Nikodemus og Josef, i genskrivningen gøres entydige. Deres sympati for Jesus eller deres hemmelige discipelskab gøres i tale og handling til entydigt troskab mod ham. Det er den grundlæggende indhold af begges vidnetaler (hhv. kap. 5 og 16,5-6).

Ud fra disse narrative teknikker er det muligt at konstatere, hvilke tendenser der sætter sig igennem i genskrivningen. De episodiske udvidelser fremviser en vilje til at udfylde alle perioder i fortællingen. 
Ligesom tilføjelsen af episoder udviser en ide om, at begivenhedernes videre forløb kan inddrages i den samme fortælling. På samme måde viser den narrative udfoldelse et ønske om, at alle detaljer skal udarbejdes i fortællinger. Tendentielt retter disse teknikker sig mod et ideal om en komplet helhed, så fortællingen ikke har tomme perioder og alle dele er fuldt narrativt udfoldet. Det er naturligvis et uopnåeligt ideal. Enhver fortælling vil kunne udvides episodisk og vil indeholde detaljer, der kan udfoldes narrativt. Teknikkernes tendens går imidlertid tydeligt fra det implicitte til det eksplicitte, så udviklingen tendentielt går mod fuldstondighed.

Det samme gør sig gældende ved figurative udfoldelser. Tendensen går også i retning af at fortælle den pågældende persons hele historie. Derfor kan den udvides fremad, som tilfældet er i Nikodemusevangeliet, hvor flere kanoniske personers historier udvides både inden for og uden for den kanoniske. Man kan sige, at figurer, der i de kanoniske evangelier optræder som "flade" bipersoner, gennem genskrivning bliver gjort til "runde" karakterer med mere fremtrædende roller. Derfor kan detaljer fra flere forskellige fortællinger samles i en person, så denne person bliver så fuldstændig beskrevet som muligt. Tendensen går således mod at skabe virkelige personer med en hel historie. Samtidig viser navngivningen af anonyme personer en tendens til konkretisering. Ved at få navn bliver personerne mere konkrete. Tendentielt retter disse teknikker sig således fra det abstrakte og ukonkrete mod det konkrete og realistiske. Udviklingen går mod realisme.

Forholdet til replikkerne i det kanoniske forlæg viste en tendens til entydighed. Hvad der i de kanoniske tekster er enigmatisk eller flertydigt bliver ved udviklingen af dialoger og udsagn gjort klart og entydigt. Det samme sker ved nye udsagn og taler. De tydeliggør den holdning, som personen ifølge genskrivningen står inde for. Tendensen går fra det tvetydige og utydelige til det utvetydige og tydelige.

Oven i disse narrative tendenser kommer en tendens til at styrke de magiske og mytologiske træk i fortællingerne. Legendariske episoder og narrative udfoldelser synes at have et stærkere mytologisk præg, hvor de overnaturlige træk fremhævet. Det samme gælder i det hele taget fremstillingen af Jesus. Han fremstår guddommelig på en måde, der endog overbyder den johannæiske fremstilling. Man kan sige, at tendensen går $\mathrm{i}$ retning af en mytologisk fremstilling, for så vidt som overnaturlige kræfter og underfulde handlinger fremhæves.

Man kan sammenfatte de narrative teknikker og tendenser således, at hypertexten tendentielt vil fortælle hypotextens historie med alle tænkelig episoder og alle detaljer narrativt udfoldet. Den vil fremstille alle personer og hele deres historie konkret og realistisk, så både 
de og deres udsagn fremstår entydigt for læseren. Ideelt vil fortællingen være et komplet, virkeligt og entydigt univers. Imidlertid er den realisme, som fortællingen tenderer mod, også gennemgribende mytologisk med overnaturlige kræfter og underfulde handlinger. Denne tendens inkorporeres i det narrative univers uden at tendensen mod realisme anfægtes. Man kan således sige, at genskrivningen stræber mod mytologisk realisme.

\section{Afslutning}

Nikodemusevangeliet er på mange måder et eksempel på en flydende tekst. Dens rammer og indhold står ikke fast og den har forandret sig og udviklet sig over århundrederne. Det er derfor ikke til at sige, hvad der er den originale tekst, og hvad der er tilføjelser og udvidelser. På den måde har den været foranderlig og levende så længe den var i brug. Af samme grund var det vanskeligt at sige noget endegyldigt om dens oprindelse.

Men man kan sige noget om dens forhold til de kanoniske skrifter. Trods deres fastlagte autoritative status forholder Nikodemusevangeliet sig ganske frit til dem. Det fortæller mere om passionshistorien, end der findes i Det Nye Testamente. Det tilføjer nye personer og udfolder kendte figurer. Det gengiver begivenheder, replikker og udsagn frit og tilføjer nye, hvor det finder det passende. Det udvider hele lidelseshistorien og fortæller om tildragelser, der er helt ukendt i de kanoniske evangelier. Mens det på mange måder sætter det samlende plot over styr, stræber det mod at inddrage så mange episoder som muligt. Bipersoner og detaljer udfoldes narrativt i skrifter i et forsøg på at få alt med. Tendentielt skal alt gøres realistisk ved at fortælle en konkret historie om det.

Man kan få den tanke, at skriftet selv er en sådan konkretisering. Justin nævnte retsakter fra processen mod Jesus. Han kendte dem dog ikke på første hånd, og der har efter al sandsynlighed ikke eksisteret sådanne skrifter på Justins tid. Men Justin sluttede sig til, at akterne i overensstemmelse med almindelig praksis måtte findes. Måske har forfatteren til Pilatusakterne gjort noget tilsvarende og - muligvis som modtræk til anti-kristne polemiske skrifter - konkretiseret dem i sin egen tekst. 